\title{
Effect of environmental conditions and genotype on nectar secretion in sunflower (Helianthus annuus L.)
}

\author{
Stan Chabert ${ }^{1, *}$, Christopher Sénéchal ${ }^{2}$, André Fougeroux ${ }^{2}$, Jérémy Pousse $^{2}$, Fabien Richard $^{1}$, \\ Emma Nozières $^{2}$, Olivier Geist ${ }^{1}$, Vincent Guillemard ${ }^{2}$, Solenne Leylavergne ${ }^{2}$, Constance Malard ${ }^{3}$, \\ Alexandre Benoist ${ }^{4}$, Gabriel Carré ${ }^{2}$, Édith Caumes $^{3}$, Charlotte Cenier ${ }^{4}$, Alain Treil ${ }^{2}$, \\ Sébastien Danflous ${ }^{2}$ and Bernard E. Vaissière ${ }^{1}$ \\ ${ }^{1}$ Institut national de recherche pour l'agriculture, l'alimentation et l'environnement (INRAE), UR406 Abeilles et Environnement, site \\ Agroparc, domaine Saint-Paul, CS 40509, 84914 Avignon cedex 9, France \\ 2 Syngenta, 12 chemin de 1'Hobit, 31790 Saint-Sauveur, France \\ 3 Arterris Innovation, 24 avenue Marcel-Dassault, 31500 Toulouse, France \\ 4 Agrosolutions, 17 rond-point de l'Europe, 51430 Bezannes, France
}

Received 1 May 2020 - Accepted 21 August 2020

\begin{abstract}
The sunflower crop provides an important honey flow for beekeepers. In France, beekeepers observed a decrease in honey yield from this crop these past years compared to the 1980s-1990s. They suspect the new cultivars to be less productive in nectar compared to the older ones, but no data is available to support this, and it is known that climate conditions have a strong impact on nectar secretion. This study aimed to explore the effect of abiotic environmental conditions on nectar secretion in sunflower, as well the range of variation of this secretion in a sample of current cultivars. Thirty-four current sunflower hybrid cultivars were sampled in test plots for their nectar secretion under varying conditions of temperature, air humidity and soil moisture. Air humidity controlled the sugar concentration of nectar, and thus its volume. To study nectar secretion independently from this effect, analyses subsequently focused on nectar sugar mass per floret. The nectar sugar mass increased with temperature up to an optimum of $32{ }^{\circ} \mathrm{C}$, while the variation range of soil water tension was not sufficient to detect an effect on nectar sugar mass. This varied by up to $100 \%$ among the 34 cultivars (from 101 to $216 \mu \mathrm{g}$ sugar per staminate floret in average), with a similar range to those reported in the literature for older cultivars. Likewise, oleic cultivars, a new type introduced since the early 2000s, were found to secrete the same amounts of nectar as linoleic cultivars, an older conventional type. The more self-fertile cultivars also showed no reduction in nectar secretion. Finally, we tested the method that measures the nectar gross secretion rate in one hybrid, and we observed that this hybrid secreted in average $28 \mu \mathrm{g}$ sugar per hour per staminate floret. The potential benefits of this method were discussed.
\end{abstract}

Keywords: nectar / sunflower / cultivars / abiotic conditions / methodology

Résumé - Effet des conditions environnementales et du génotype sur la sécrétion de nectar chez le tournesol (Helianthus annuus L.). Le tournesol constitue une miellée importante pour les apiculteurs. En France, les apiculteurs ont constaté des baisses de miellées sur cette culture ces dernières années par rapport aux années 1980-1990. Ils suspectent les nouvelles variétés d'être moins nectarifères que les plus anciennes, mais aucune donnée ne permet de l'établir, et l'on sait que les conditions climatiques ont un fort impact sur la sécrétion de nectar. Cette étude avait pour objectif d'explorer l'effet des conditions environnementales abiotiques sur la sécrétion de nectar chez le tournesol, ainsi que la gamme de variation de cette sécrétion sur un échantillon de variétés courantes. Trente-quatre variétés hybrides actuelles de tournesol ont été échantillonnées dans des micro-parcelles pour leur sécrétion nectarifère dans des conditions variables de température et d'humidité de l'air et du sol. L'humidité de l'air contrôlait la concentration du nectar et donc son volume. Pour s'affranchir de cet effet, l'analyse a porté ensuite sur la masse de sucres sécrétée par

\footnotetext{
${ }^{*}$ Correspondence: stan. chabert@inrae.fr
} 
fleuron. Cette masse de sucres a augmenté avec la température jusqu'à un optimum de $32^{\circ} \mathrm{C}$, tandis que la gamme de variation de la tension hydrique du sol n'a pas été suffisamment importante pour observer une diminution de la masse de sucres par fleuron. Cette masse de sucres a varié du simple au double parmi les trente-quatre variétés étudiées (de 101 à $216 \mu \mathrm{g}$ de sucres par fleuron staminé en moyenne), mais la gamme de variation observée n'était pas différente de celles rapportées dans la littérature pour des variétés plus anciennes. De même, les variétés oléiques, type nouveau introduit depuis le début des années 2000, ne se sont pas révélées moins nectarifères que le type linoléique conventionnel, plus ancien. Les variétés plus auto-fertiles n'étaient pas non plus moins nectarifères. Enfin, nous avons testé la méthode qui mesure le taux de sécrétion brut du nectar sur un hybride, et nous avons observé que cet hybride sécrétait en moyenne $28 \mu \mathrm{g}$ de sucres par heure par fleuron staminé. Les potentiels avantages de cette méthode ont été discutés.

Mots clés : nectar / tournesol / variétés / conditions abiotiques / méthodologie

\section{Introduction}

Studying floral nectar secretion of entomophilous crops can be of importance for crop production, as the more a crop secretes floral nectar, the more it is visited by pollinators (Prasifka et al., 2018). It is especially so in the case for sunflower (Helianthus annuus; Asteraceae) (Tepedino and Parker, 1982; Mallinger and Prasifka, 2017), for which an average of 0.2 bees per head is sufficient to maximise seed yield and oil content (Chabert et al., 2019, in prep). Therefore, entomophilous crops need to be attractive enough to get enough pollinator visits so that their yields are not limited by a pollination deficit.

On the other hand, entomophilous crops can be a source of nectar relied upon by beekeepers to produce honey, especially oilseed crops such as sunflower (Breeze et al., 2019). In France, to explain the decrease of honey yields observed in this crop since the 1980's and 1990's (Cerrutti and Pontet, 2016), some beekeepers suspect recent cultivars to secrete less nectar compared to the older ones, in particular oleic cultivars, carrying a type introduced since the early 2000s (Tonin, 2018). Some beekeepers also suspect breeding for self-fertility to have led to cultivars that are less productive in nectar. Unfortunately, no official data is available to support these contentions.

Several studies observed differences in the quantities of nectar secreted between lines or cultivars of sunflower, at the floret or the whole plant scale (Tepedino and Parker, 1982; Hadisoesilo and Furgala, 1986; Vear et al., 1990; Zajácz et al., 2006; Ion et al., 2007; Mallinger and Prasifka, 2017). These differences may be explained in part by differences in nectary size between genotypes (see Dafni et al., 1988; Petanidou et al., 2000; Galetto and Bernardello, 2004). This was the hypothesis adopted by Sammataro et al. (1985) for sunflower. Additionally, there does not seem to be a difference in the quantity of nectar secreted at the floret level between male sterile lines on one hand, and male fertile lines on the other hand (see Fig. 1; Tepedino and Parker, 1982; Vear et al., 1990; Mallinger and Prasifka, 2017), unlike for instance oilseed rape (Brassica napus L.) (Pierre et al., 1999; Chabert et al., 2017). No differences in floret size, and even more, in nectary size have been reported between these two genetic types in sunflower.

In oilseed rape, despite differences of nectar secretion also observed between lines or cultivars (Szabo, 1982; Pierre et al.,
1999; Bertazzini and Forlani, 2016; Carruthers et al., 2017; Ouvrard et al., 2017), Pierre and Emeillat (2009) found that the low numbers of honey bee visits to flowers observed by beekeepers in the early 2000 s were due more to adverse weather conditions than to new cultivars which were not particularly unproductive in nectar. Indeed, nectar secretion is directly dependent on temperature and soil moisture. Nectar secretion increases with temperature up to an optimum, and then decreases (Kenoyer, 1917; Findlay et al., 1971; Villarreal and Freeman, 1990; Nicolson, 1995; Petanidou and Smets, 1996; Takkis et al., 2015, 2018; Chabert et al., 2017). It decreases as soil water tension or plant water stress increase (Villarreal and Freeman, 1990; Carroll et al., 2001; Descamps et al., 2018, 2020; Phillips et al., 2018), and thus increases with soil moisture (Wyatt et al., 1992; Waser and Price, 2016; Gallagher and Campbell, 2017; Mueller et al., 2020). However, Gillespie et al. (2015) observed an optimum of soil moisture beyond which nectar secretion decreased. This sensitivity to soil water tension varies with the genotype (Boose, 1997; Leiss and Klinkhamer, 2005; Suni et al., 2020), or with stresses applied on plants (Lindström et al., 2018). In particular, genotypes that develop a large root mass may be more tolerant to high soil water tensions than genotypes which have a smaller root mass (Leiss and Klinkhamer, 2005; Masalia et al., 2018).

Sugar concentration of nectar is also directly dependent on relative humidity $(\mathrm{RH})$ of ambient air: low $\mathrm{RH}$ leads to fast evaporation of nectar water, and thus to a high sugar concentration, while conversely high RH limits evaporation of nectar water and maintains a lower sugar concentration (Pacini and Nepi, 2007), close to that of phloem sap, as the nectaries are supplied by the phloem in the Asteraceae (Sammataro et al., 1985; Pacini et al., 2003; Wist and Davis, 2006, 2008).

This study aimed to explore $(i)$ the effect of abiotic environmental conditions on nectar secretion in sunflower, i.e. air humidity, air temperature, soil moisture, and time of day, and (ii) the range of variation of nectar secretion among several current sunflower hybrids. In particular, the nectar secretion of some oleic cultivars was compared to that of several linoleic cultivars (the linoleic type being a more conventional and older type than the oleic one), and we also tested the possible correlation between the level of nectar secretion and the level of self-fertility in this pool of cultivars. Finally, we tested another method to measure the nectar secretion, the one which measures the gross secretion rate. 


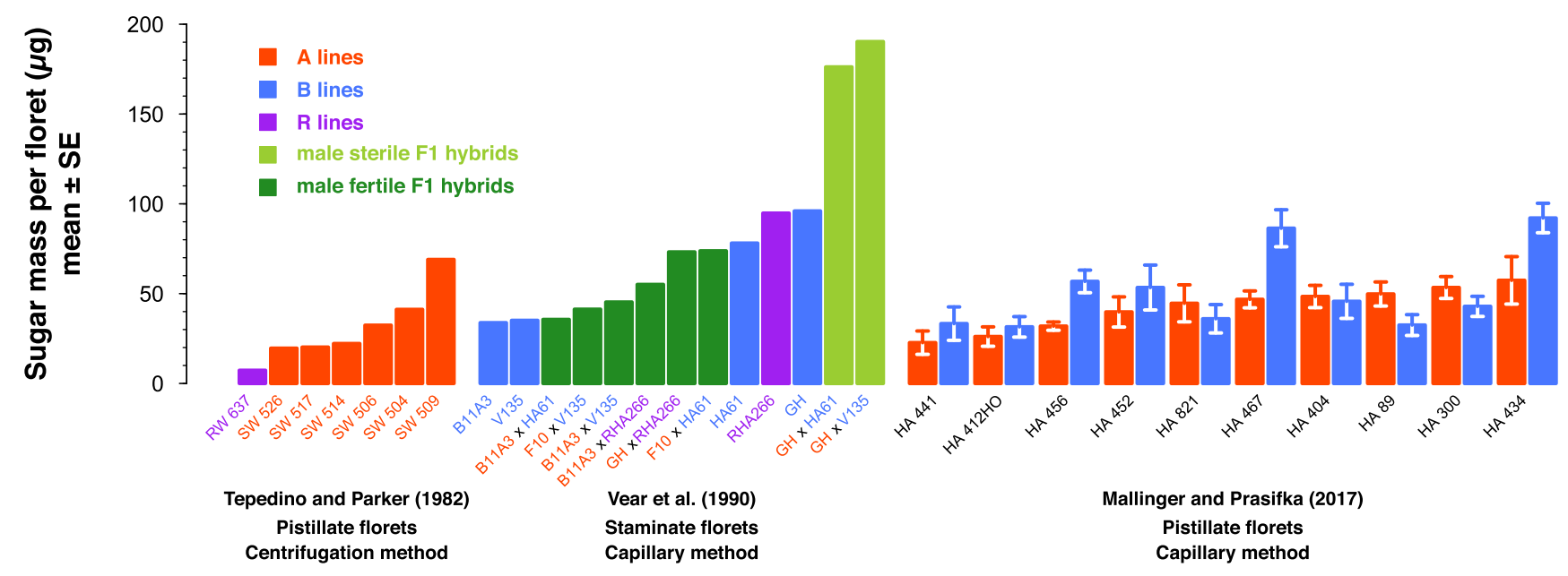

Fig. 1. Comparison of apparent nectar secretion between different types of sunflower genotypes, from three studies. A line: genic or cytoplasmic male sterile line; B line: male fertile line; R line: male fertile line provided with the restorer nuclear gene of fertility. Male sterile F1 hybrid: result of a cross between a cytoplasmic male sterile line and a B line. Male fertile F1 hybrid: result of a cross between a genic male sterile line (recessive allele) and a B line, or between a cytoplasmic male sterile line and an $\mathrm{R}$ line. The reference studies are given with the sampled floret stage and the method of nectar extraction. The sugar mass data of Tepedino and Parker (1982) and Vear et al. (1990) were calculated using the formula of Cruden and Hermann (1983) from the nectar volume and the sugar concentration (measured by gas chromatography in Vear et al., 1990) given for each genotype in the respective Tables 1 of these studies. The data of Mallinger and Prasifka (2017) were recovered using Plot Digitizer 2.6.8 (http://plotdigitizer.sourceforge.net/) from their Figure 1a.

\section{Materials and methods}

\subsection{Nectar sampling}

To meet these objectives, 34 current oilseed F1 hybrid cultivars of sunflower, coded from 1 to 34 , were sampled in test plots of the Syngenta site of Lombez, France. Twenty-three of these cultivars were oleic, and the remaining 11 others were linoleic. Two plots per cultivar were sown two weeks apart in April each year to extend the sampling period during flowering and they were distributed at random among the plots. The measures were made in July 2016-2019, between 07:00 $\mathrm{h}$ and 17:00 h GMT on at least four dates per cultivar each year. Plants were regularly watered to avoid an excessive water stress. For each cultivar and each sampling date, three heads chosen at random among those in the R5.3-R5.6 stage (reproductive stage with $30-60 \%$ of the head florets open) were isolated under tulle bags of $1 \mathrm{~mm}$ mesh size (cloth F510, Diatex, France) the day before to prevent insect foraging. As nectar secretion can be very variable from one floret to another depending on the head region, four florets at the staminate stage (Fig. 2) were sampled per head from four regions: at the top, bottom, left and right of the head.

Nectar volume was extracted and measured in each floret with microcapillary tubes of $1 \mu \mathrm{L}$ (intraEND, Blaubrand, Germany; or microcaps , Drummond, USA; or minicaps , Hirschmann , Germany; Fig. 3). Sugar concentration was measured with hand-held refractometers Eclipse 45-81 (0$50 \%$ Brix) or $45-82$ (45-80\% Brix), adapted for small volumes (Bellingham and Stanley Ltd., UK). Nectar volume and sugar concentration were then converted into sugar mass per floret with the formula of Cruden and Hermann (1983):

$$
M=V C(0.000046 C+0.009946)
$$

where $M$ is the sugar mass in $\mu \mathrm{g}, V$ the nectar volume in $\mathrm{nL}$, and $C$ the sugar concentration in $\mathrm{g}$ of sugar per $100 \mathrm{~g}$ of solution (\% Brix). This method made it possible to assess the apparent nectar secretion rate (Corbet, 2003), hereafter called ASR.

\subsection{Abiotic environmental conditions}

Air temperature and relative humidity were recorded every hour during flowering with one sensor placed in a shelter in the centre of the plots. Soil moisture was measured with a Watermark sensor (Irrometer, , USA) that recorded soil water tension at a depth of 30 and $60 \mathrm{~cm}$ once a day.

\subsection{Rate of self-fertility}

The self-fertility rate of twenty cultivars was measured in test plots of the Syngenta ${ }^{\circledR}$ site of Grisolles, France, in 2018 and 2019. Each cultivar was sown on two plots side by side each year. One plot was covered by a cage made of screen with $1 \times 1 \mathrm{~mm}^{2}$ mesh opening during flowering to isolate heads from insect pollination, while the other plot was left for open pollination. Twenty heads chosen at random were harvested at physiological maturity in each plot each year to assess the mean seed set per pollination treatment per year. The self-fertility rate was calculated for each year and each cultivar by dividing the number of seeds obtained on the 20 heads isolated under the cage by the number of seeds on the 20 open pollinated heads. The self-fertility rates calculated each year per cultivar were averaged over all of the years per cultivar. 


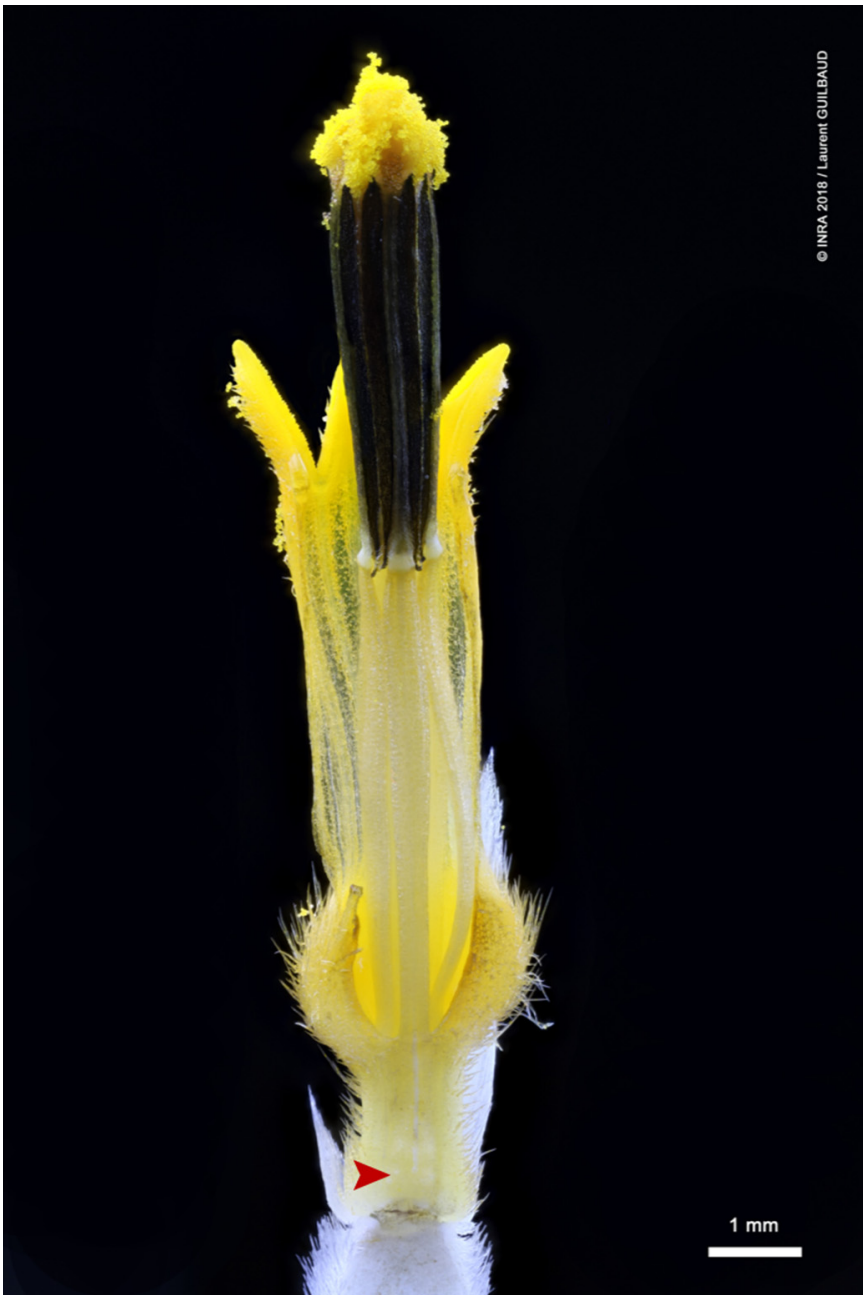

Fig. 2. Sunflower floret at the staminate stage. Red arrow shows the nectary position, located at the very base of the floret, just above the ovule (according to Sammataro et al., 1985). (C) Laurent Guilbaud, INRAE.

\subsection{Other measure of nectar secretion: the gross secretion rate}

The measure of the nectar gross secretion rate (Corbet, 2003), hereafter called GSR, was tested on one date (July 24, 2018) on one oleic cultivar (cv. 31), with four staminate florets per head on six heads. This method consisted first in emptying the florets of their nectar at 07:30h GMT, which was equivalent to measure the ASR at this time, then again extracting the nectar in the same florets at 10:30 h GMT, then again at 13:30 h GMT. This method enabled us to assess the quantity of nectar secreted per floret during three hours, between $07: 30 \mathrm{~h}$ and 10:30 $\mathrm{h}$ GMT and then between 10:30 h and 13:30 h GMT, and thus to calculate the quantity of nectar secreted per hour.

\subsection{Data analysis}

\subsubsection{Air humidity}

The relation between the nectar sugar concentration per floret and the air humidity at the time of nectar extraction from

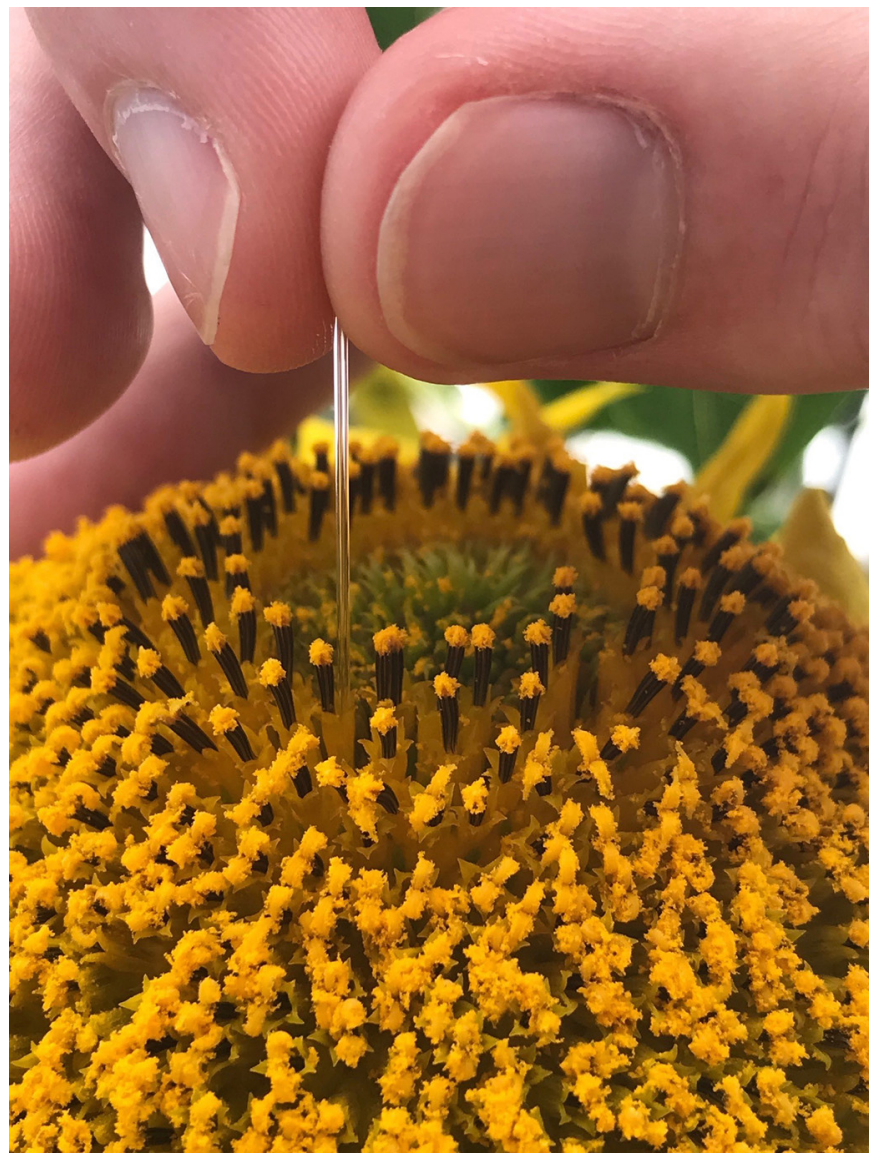

Fig. 3. Nectar extraction in a sunflower floret at the staminate stage with a microcapillary tube of $1 \mu \mathrm{L}$. (C) Mathieu Mourereau, Syngenta .

the floret (within half an hour) was analysed by comparing two models, each using a different variable to describe air humidity. The first model used the relative drought (RD) of ambient air as explanatory variable, which was calculated as follows:

$$
R_{D}=100-R_{H}
$$

where $R_{D}$ is the relative drought in $\%$, and $R_{H}$ is the relative humidity in $\%$.

The second model used the vapour pressure deficit (VPD) of ambient air as explanatory variable, which measures the gap between the saturation vapour pressure and the observed vapour pressure. VPD integrates that the amount of water vapour that the air can hold varies with temperature (see Grossiord et al., 2020). The VPD was calculated as follows (Allen et al., 1998):

$$
V_{P D}=0.6108 \mathrm{e}^{\frac{17.27}{(237.3+T)}}\left(1-R_{H} / 100\right)
$$

where $V_{P D}$ is the vapour pressure deficit in $\mathrm{kPa}$, and $T$ is the temperature in ${ }^{\circ} \mathrm{C}$.

We used the two models to analyse the relation between sugar concentration and humidity with a piecewise polynomial function with one breakpoint (Bolker, 2008): when sugar concentration is not in equilibrium with the air humidity level of the air humidity (Pacini and Nepi, 2007), the sugar concentration $C$ increases linearly with RD or VPD up to reach 
a maximum beyond which nectar water can no longer evaporate. This function is written as follows:

$$
\left\{\begin{array}{l}
\text { if } X<d_{0}, C=\frac{c_{\max }-c_{o}}{d_{o}} x+c_{0} \\
\text { if } X>d_{0}, C=c_{\max }
\end{array}\right.
$$

where $C$ is the sugar concentration, $X$ is the air drought level expressed either by RD or VPD, $c_{0}$ is the intercept, $c_{\text {max }}$ is the maximum sugar concentration beyond which nectar water can no longer evaporate, and $d_{0}$ is the air drought level at which $C$ reaches $c_{\max }$.

\subsubsection{Air temperature}

The relation between the mass of nectar sugar per floret and the air temperature at the time of nectar extraction from the floret (within half an hour) was analysed by using the equation proposed by Yin et al. (1995) and Yan and Hunt (1999) to model the temperature response of plants following a beta distribution from the cardinal temperatures (Eq. (8c) in Yin et al., 1995; Eq. (3) in Yan and Hunt, 1999):

$\left\{\begin{array}{l}\text { if } T \leq t_{\max }, M=m_{\max }\left[\left(\frac{t_{\max }-T}{t_{\max }-t_{\text {opt }}}\right)\left(\frac{T-t_{\min }}{t_{\text {opt }}-t_{\min }}\right)^{\frac{t_{\text {opt }}-t_{\text {min }}}{t_{\max }-t_{\text {opt }}}}\right]^{a} \\ \text { if } T>t_{\max }, M=0\end{array}\right.$

where $T$ is the ambient air temperature, $m_{\max }$ is the maximum sugar mass secreted per floret at the optimum temperature $t_{\text {opt }}$, $t_{\text {min }}$ is the minimum temperature below which nectar secretion is nil, $t_{\max }$ is the maximum temperature above which nectar secretion is nil again, and $\alpha$ is a parameter that determines the shape of the curve.

\subsubsection{Soil moisture and time of day}

The effects of soil water tension and time of day were tested on the sugar mass per floret with two linear mixed models. The cultivar, year, date, plot and plant were set as random variables.

\subsubsection{Genotype}

The cultivars were sorted in ascending order of mean sugar mass secreted per floret. Their range of mean sugar masses was compared descriptively with those of Hadisoesilo and Furgala (1986), Vear et al. (1990), Zajácz et al. (2006), and Ion et al. (2007) for hybrids. The data of sugar mass per floret of Vear et al. (1990) were obtained using equation (1) from the nectar volume and the dry matter percentage measured by gas chromatography (as the authors recommend this method compared with that using enzyme electrode) given in their Table 1. Hadisoesilo and Furgala (1986) measured sugar mass by centrifugation of florets at the pistillate stage, while Vear et al. (1990) used microcapillary tubes on florets at the staminate stage, and Zajácz et al. (2006) and Ion et al. (2007) used microcapillary tubes on florets of unspecified stage.

The mean sugar mass per floret was compared between oleic and linoleic cultivars with a linear mixed model, with the cultivar, year, date, plot and plant set as random variables. The correlation between the sugar mass per floret and the rate of selffertility per cultivar was tested with a Pearson correlation test.

\subsubsection{Gross secretion rate}

The mean nectar volume, sugar concentration and sugar mass per floret were compared between the ASR measured at 07:30 $\mathrm{h}$ GMT and the GSR measured at 10:30 $\mathrm{h}$ and 13:30 $\mathrm{h}$ GMT on July 24, 2018 on the cultivar 31 with three linear mixed models, with the plant and the floret set as random variables.

\subsubsection{Statistical methods, software, packages and P- value threshold}

The parameters of the mechanistic models were estimated with the nonlinear least squares (Bolker, 2008). These models were compared between them and with the null model with Akaike information criterion (AIC; Burnham and Anderson, 2002). The coefficients of determination of these models were calculated by the deviance ratio $R_{\mathrm{D}}^{2}$ (Nakagawa and Schielzeth, 2013).

All the statistics were computed with the software R, version 3.2.0 ( $\mathrm{R}$ Core Team, 2015). Asymptotic 95\% confidence intervals $(95 \% \mathrm{CI})$ of mechanistic model parameters were estimated with the package nlstools, version 1.0-2 (Baty et al., 2015). The mixed effects models were computed with the package lme4, version 1.1-15 (Bates et al., 2015). The $\mathrm{P}$-values of the linear mixed effects models were obtained with the package lmerTest, version 2.0-36 (Kuznetsova et al., 2017). The chosen P-value threshold for statistical significance was 0.005 , as recommended by Johnson (2013) and Benjamin et al. (2018).

\section{Results and discussion}

\subsection{Air humidity}

Nectar sugar concentration was very variable, from $8 \%$ up to almost $80 \%$, with a VPD ranging from 0.1 to $4.4 \mathrm{kPa}$. VPD was more suitable than RD to explain the variation of sugar concentration (Tab. 1). Sugar concentration increased with VPD, from a predicted mean concentration of $23.2 \%$ when the air was saturated in humidity, a concentration probably close to that at which the nectar is secreted, to a mean maximum concentration of $55.6 \%$ at a VPD of $0.75 \mathrm{kPa}$ (Tab. 1; Fig. 4a). VPD explained $55.6 \%$ of the variation in sugar concentration. To study nectar secretion independently of this effect, the quantity of nectar was subsequently analysed based on the sugar mass produced, and not according to the volume secreted. For information, sugar concentration was also showed in relation with relative humidity (Fig. 4b).

\subsection{Soil moisture}

Despite a large variation of soil water tension (from 0 to 240 Centibars at $30 \mathrm{~cm}$ deep and from 0 to 200 Centibars at $60 \mathrm{~cm}$ deep), the sugar mass did not vary with the increase in water tension, measured either at $30 \mathrm{~cm}$ deep $(t=2.58 ; P=0.012$; Fig. 5a) or at $60 \mathrm{~cm}(t=2.49 ; P=0.017 ;$ Fig. $5 b)$. This is probably 
Table 1. Statistics of the piecewise polynomial models (Eq. (2)) between nectar sugar concentration in the floret and air humidity, approximated either by the relative drought or by the vapour pressure deficit.

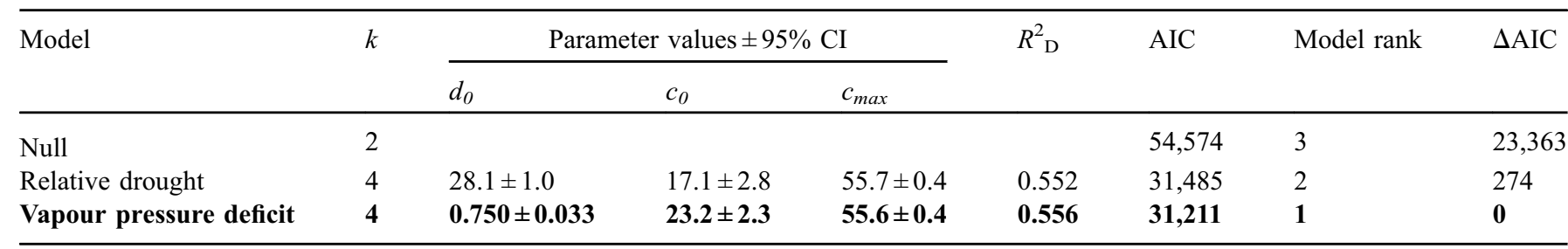

$k$ : number of estimated parameters per model; $\mathrm{CI}$ : confidence interval; $R^{2}{ }_{\mathrm{D}}$ : coefficient of determination calculated by the deviance ratio; model rank: model ranking by increasing AIC value; $\triangle \mathrm{AIC}$ : AIC value minus the lowest AIC; $d_{0}$ : drought level at which the sugar concentration reaches $c_{\text {max }} ; c_{0}$ : intercept; $c_{\max }$ : maximum sugar concentration beyond which nectar water can no longer evaporates. The model in bold is the one with the minimum AIC value.

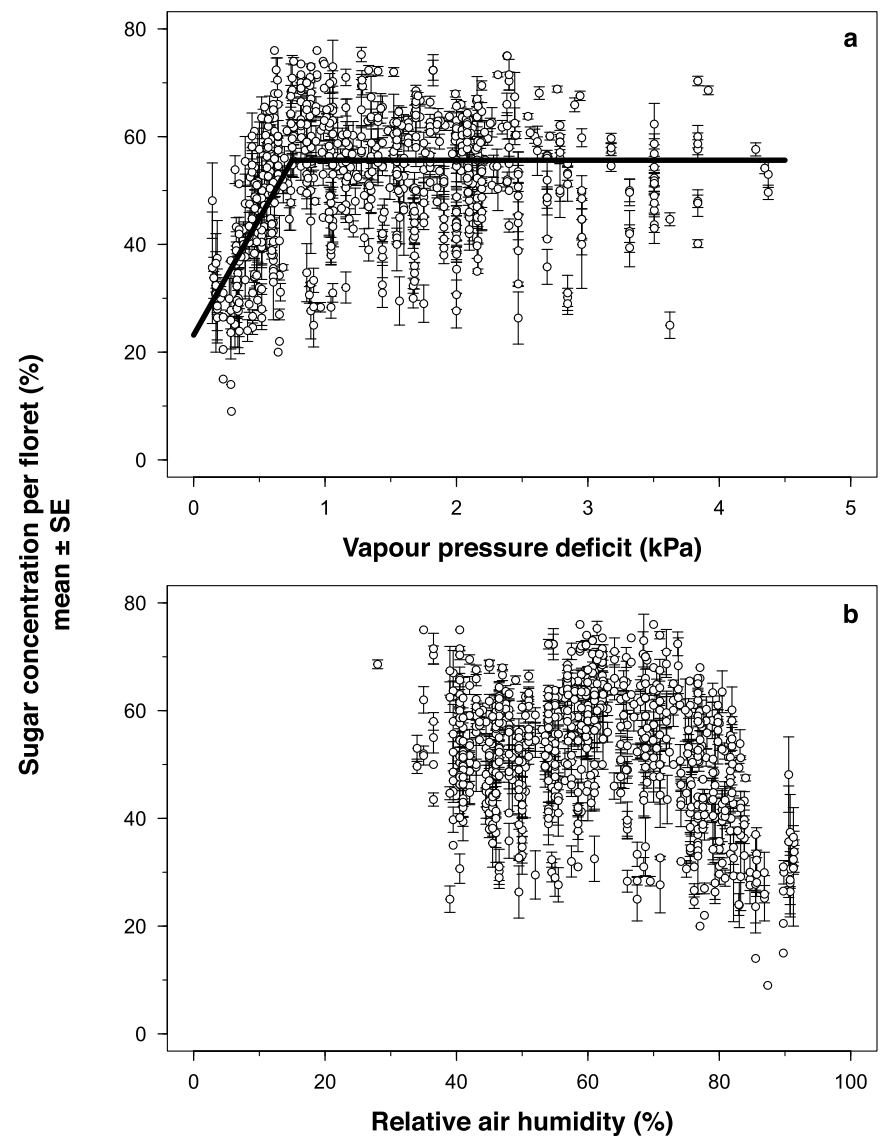

Fig. 4. Relation between sugar concentration per floret and the vapour pressure deficit (VPD) (a) or the relative air humidity (b) at the time of nectar extraction. Solid line depicts Eq. (2) with parameters given in Table 1.

due to the fact that plants were regularly watered, avoiding excessive water stress. Higher soil water tensions would probably have been necessary to detect a threshold of water stress impacting nectar secretion.

\subsection{Time of day}

Nectar sugar mass per floret increased with the time of day between 07:00 h and 17:00 h GMT at a mean rate of $8.0 \mu \mathrm{g} . \mathrm{h}^{-1}$

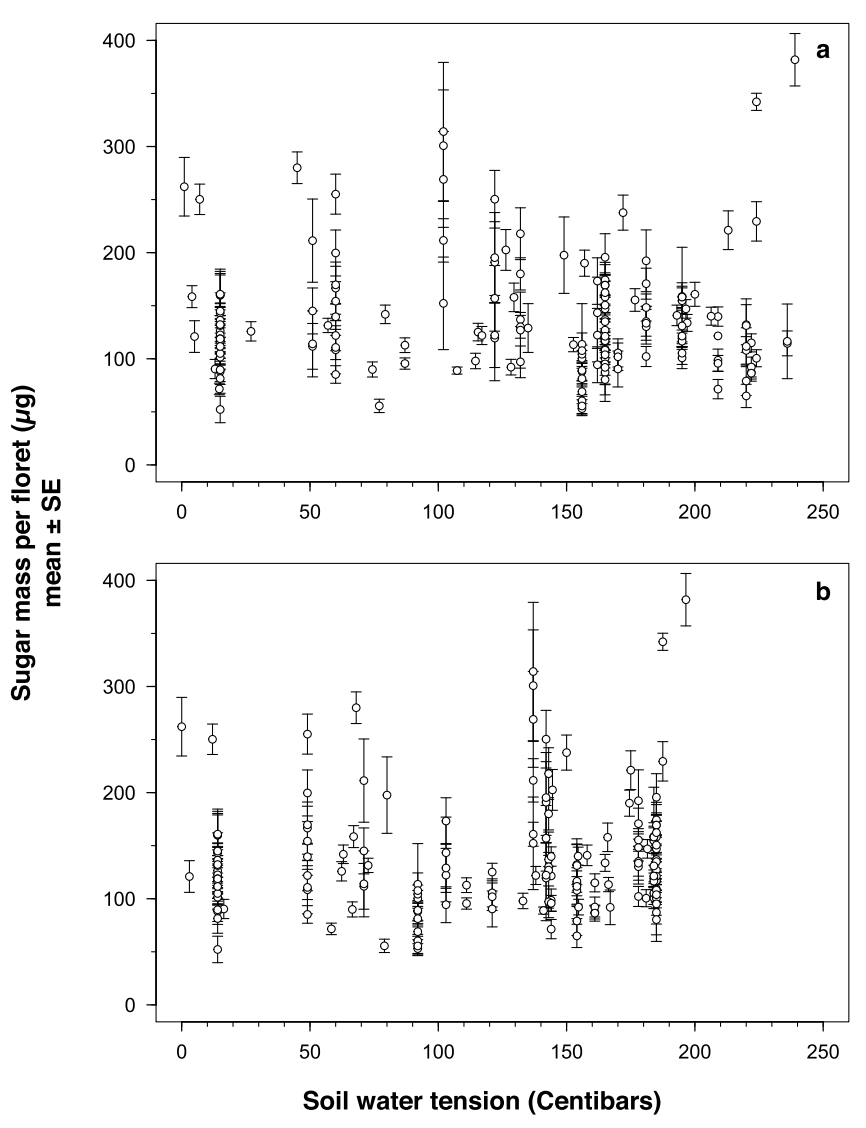

Fig. 5. Relation between nectar sugar mass per floret and the soil water tension at 30 (a) or 60 (b) $\mathrm{cm}$ deep.

on the overall range of cultivars sampled $( \pm 3.8,95 \% \mathrm{CI}$; $t=4.16 ; P<0.005$; Fig. 6).

\subsection{Air temperature}

Nectar sugar mass per floret increased with air temperature over the range of $16-32^{\circ} \mathrm{C}$ and appeared to decrease beyond $32{ }^{\circ} \mathrm{C}$ on the overall range of cultivars sampled (Tab. 2; Fig. 7). However, a true estimation of $t_{o p t}, t_{\min }$ and $t_{\max }$ would have required temperatures below $16^{\circ} \mathrm{C}$ and also above $35^{\circ} \mathrm{C}$. Furthermore, the temperature at the time of nectar extraction 


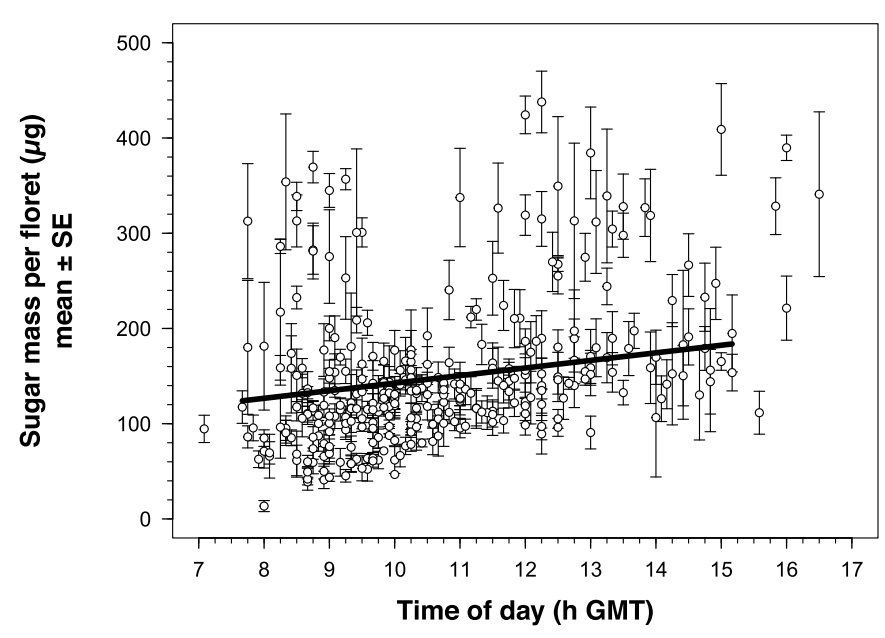

Fig. 6. Relation between nectar sugar mass per floret and the time of day. Solid line depicts the predictions of the linear mixed model.

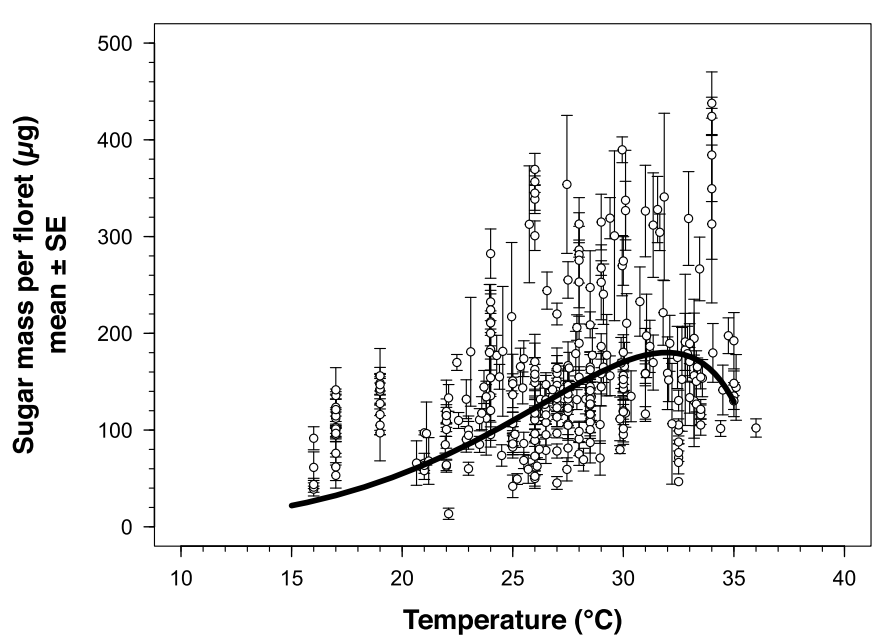

Fig. 7. Relation between nectar sugar mass per floret and the temperature at the time of nectar extraction. Solid line depicts the predictions of Eq. (3) with parameters given in Table 2.

Table 2. Statistics of the beta distribution model (Eq. (3)) between nectar sugar mass per floret and air temperature.

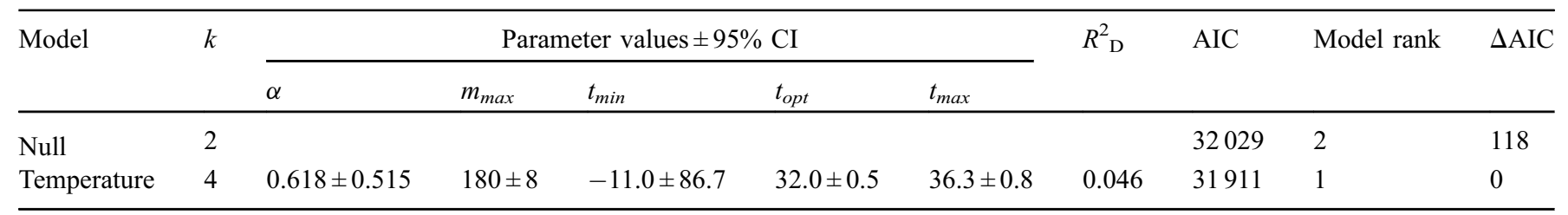

$k$ : number of estimated parameters per model; CI: confidence interval; $R^{2}{ }_{\mathrm{D}}$ : coefficient of determination calculated by the deviance ratio; model rank: model ranking by increasing AIC value; $\triangle \mathrm{AIC}$ : AIC value minus the lowest AIC; $\alpha$ : parameter that determines the shape of the curve; $m_{\max }$ : maximum sugar mass secreted per floret at the optimum temperature $t_{\text {opt }} ; t_{\min }, t_{\max }$ : respectively minimum, maximum, temperature below and above which nectar secretion is nil.

from the floret does not depict the real temperature range met by the floret during all the secretion process. To test this variable correctly, the method that measures the nectar GSR should have been used instead, by associating the sugar mass measured in the floret with the average of the temperatures met by the floret between the time it was emptied and the time of measurement (see for instance Nicolson, 1995; Chabert et al., 2017).

\subsection{Genotype}

As in other studies, the nectar sugar mass secreted per floret varied among cultivars sampled, ranging from 101 to $216 \mu \mathrm{g}$ sugar per floret on average (Fig. 8), with no difference between the oleic and linoleic types $(t=0.46 ; P=0.649)$. This range is similar to those observed by Vear et al. (1990) with eight hybrids (ranging from 36 to $190 \mu \mathrm{g}$ sugar per floret; see Fig. 8), by Zajácz et al. (2006) with 19 hybrids (ranging from 40 to $100 \mu \mathrm{g}$ sugar per floret), and by Ion et al. (2007) with 33 hybrids (ranging from 70 to $250 \mu \mathrm{g}$ sugar per floret; see Fig. 8). However, this range is lower than that observed by Hadisoesilo and Furgala (1986) with 18 oilseed hybrids, ranging from 303 to $491 \mu \mathrm{g}$ sugar per floret. But in their study, the nectar was extracted by centrifugation of pistillate florets, while this method artificially dilutes the nectar and it may add sugars from damaged plant tissue cells (Mesquida et al., 1988; Vear et al., 1990). From these few elements of literature, it is therefore not possible to assert that current hybrids secrete less nectar than those from the 1980's or 2000's.

Furthermore, the data available show no evidence for a negative correlation between the amount of nectar secreted and the level of self-fertility of the hybrids studied $(R=-0.17$; $P=0.473$; Fig. 9). If these two traits are not genetically linked, there is no reason to expect that they should be inversely correlated. While it is true that nectar secretion can be costly for plants (Southwick, 1984; Pyke, 1991), natural selection does not operate alone in crop selection programs. More investigations are necessary to conclude on this link since the rate of self-fertility can be quite variable for one cultivar according to where it is grown (Chabert et al., in prep). Nectar secretion and self-fertility should be measured in the same field, which was not the case in our study.

\subsection{Other measure of nectar secretion: the gross secretion rate}

By emptying the florets with the method that measures the nectar GSR, sugar concentration was $20.4 \%$ at 10:30 h GMT and $14.6 \%$ at $13: 30 \mathrm{~h} \mathrm{GMT}$, while it was $50.1 \%$ at $07: 30 \mathrm{~h}$ GMT with the ASR method (Tab. 3; Fig. 10b). As the mean 
S. Chabert et al.: OCL 2020, 27, 51

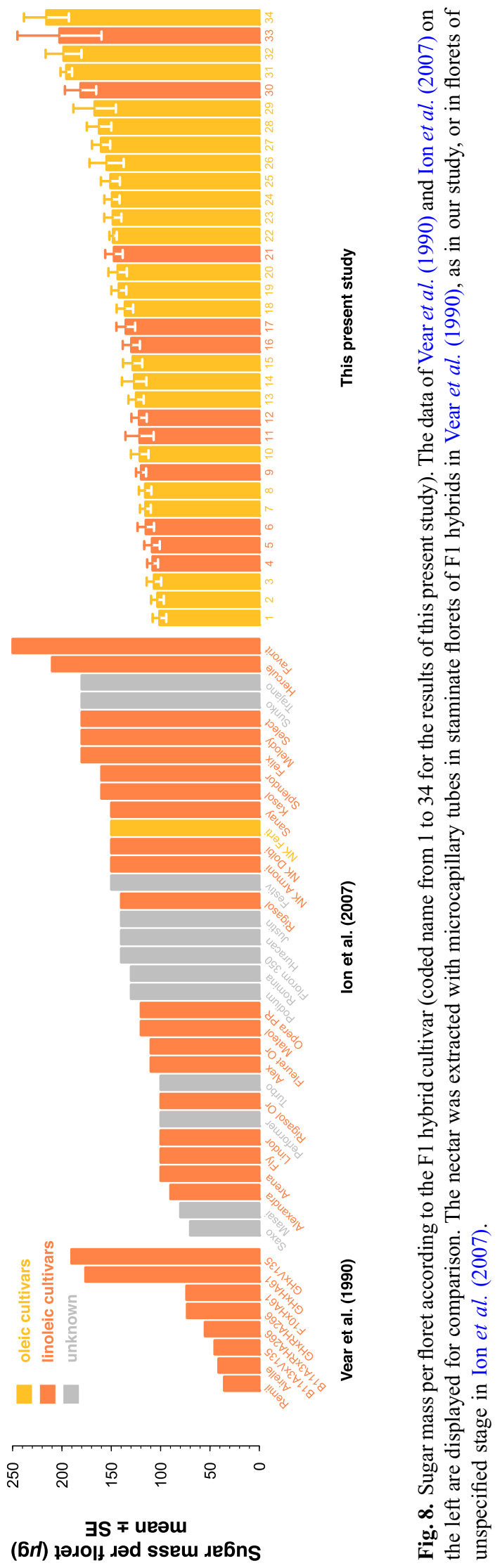

Page 8 of 12 
Table 3. Pairwise comparisons of the mean nectar quantity and sugar concentration per floret between the two measure methods used and the three times of measurement (see Fig. 10).

\begin{tabular}{|c|c|c|c|c|c|c|c|c|c|}
\hline \multirow[t]{2}{*}{ Compared treatments } & \multicolumn{3}{|c|}{ Nectar volume (nL) } & \multicolumn{3}{|c|}{ Sugar concentration (\%) } & \multicolumn{3}{|c|}{ Sugar mass $(\mu \mathrm{g})$} \\
\hline & $\beta \pm \mathrm{SE}$ & $t$ & $P$ & $\beta \pm \mathrm{SE}$ & $t$ & $P$ & $\beta \pm \mathrm{SE}$ & $t$ & $P$ \\
\hline GSR 10:30 versus ASR 07:30 & $242 \pm 50$ & 4.84 & $<0.005$ & $-29.8 \pm 2.8$ & -10.8 & $<0.005$ & $-13.3 \pm 9.1$ & -1.47 & 0.150 \\
\hline GSR $13: 30$ versus ASR 07:30 & $416 \pm 53$ & 7.82 & $<0.005$ & $-35.7 \pm 2.9$ & -12.4 & $<0.005$ & $-5.4 \pm 9.6$ & -0.56 & 0.579 \\
\hline GSR $13: 30$ versus GSR $10: 30$ & $174 \pm 55$ & 3.17 & $<0.005$ & $-5.9 \pm 2.9$ & -2.05 & 0.047 & $7.9 \pm 9.8$ & 0.81 & 0.425 \\
\hline
\end{tabular}

GSR: gross secretion rate; ASR: apparent secretion rate.

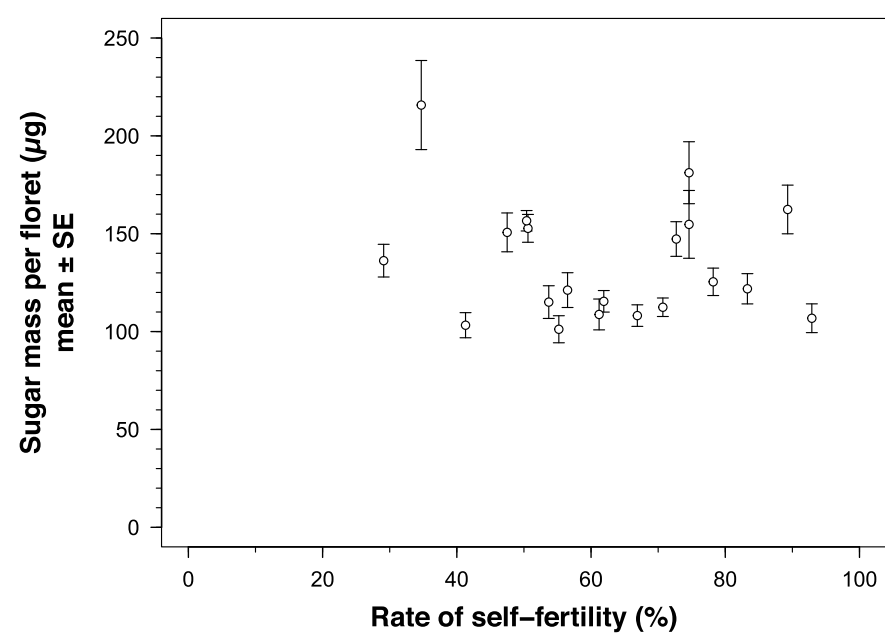

Fig. 9. Nectar sugar mass per floret and per cultivar in relation with their rate of self-fertility.

sugar masses were similar at the three measurement times with the two methods (Tab. 3; Fig. 10c), the ASR method yielded a lower nectar volume than the GSR method (Tab. 3; Fig. 10a). This result indicates that by regularly emptying the florets, as happens with foraging by bees, the nectar had less time to evaporate and its concentration was probably closer to that of the phloem sap. The sugar concentration measured with the GSR method was close to that of $23.2 \%$ estimated at zero VPD with the ASR method (see Sect. 3.1). The classic ASR method may therefore artificially overestimates the sugar concentration encountered by bees when they forage, as it was still observed in other plant species (Raw, 1953 and references therein; Nicolson, 1993; Galetto and Bernardello, 2004; Mione and Diaz, 2020).

In addition, nectar secretion is a dynamic process. Nectar is either secreted during a short time during the day or the night when it is derived from starch stored in parenchyma, or nectar is secreted in a continuous way during the daytime when nectar is directly derived from photosynthesis through phloem sap (Cruden et al., 1983; Pacini et al., 2003; Pacini and Nepi, 2007). Asteraceae belong to this latter category. Their nectaries are directly connected to the phloem sap through sieve tubes, and there is no starch storage in parenchyma (Sammataro et al., 1985; Pacini et al., 2003; Wist and Davis, 2006, 2008). Therefore, Asteraceae secrete nectar in a continuous way during the daytime. The GSR method may enable one to capture this dynamic process, by dividing the sugar mass extracted in a floret by the time elapsed between the initial
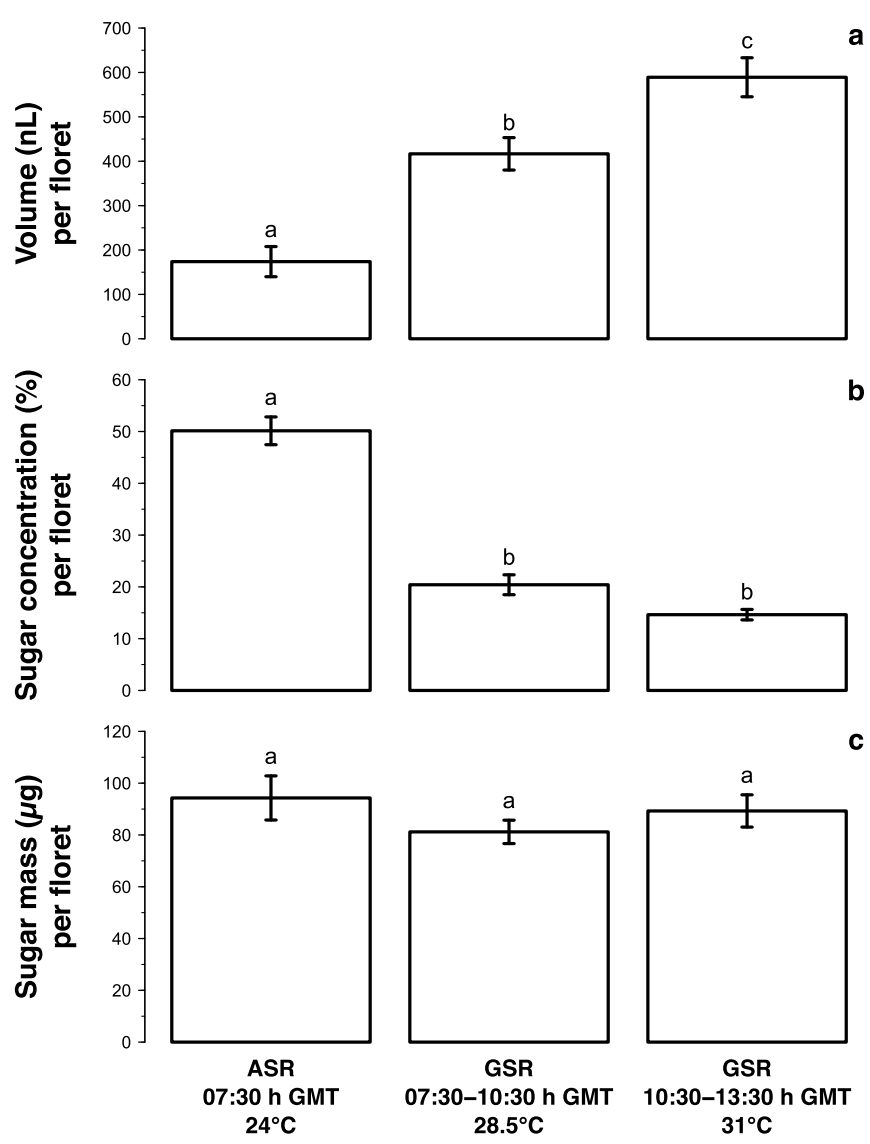

Fig. 10. Nectar quantity and sugar concentration (mean $\pm S E$ ) per floret according to the method used: apparent secretion rate (ASR) or gross secretion rate (GSR). Measures done on July 24, 2018, on cultivar 31 .

emptying time of the floret and the time of measurement. Florets secreted an average of $85 \mu \mathrm{g}$ sugar in three hours between 07:30 $\mathrm{h}$ and 10:30 $\mathrm{h} \mathrm{GMT}$, as well as between 10:30 h and 13:30 h GMT, giving an average rate of $28 \mu \mathrm{g} . \mathrm{h}^{-1}$ sugar. In addition, many studies showed in other species that by regularly extracting the nectar from a flower, as it may happen with animal foraging and as it happens with the GSR method, repeatedly sampled flowers secrete more nectar in total than flowers sampled just once (e.g. Raw 1953; Búrquez and Corbet, 1991; Nicolson 1993, 1995; Castellanos et al., 2002; Luo et al., 2014; Mione and Diaz, 2020). This is explained by the fact that regularly extracting the nectar from the flower 
inhibits the resorption process which occurs concomitantly with the secretion process (Nepi and Stpiczyńska, 2008). Therefore, to estimate the total sugar mass produced by one hectare of sunflower crop foraged by bees, one should estimate the GSR of this crop and multiply it by the nectar secretion period (e.g. Chabert et al., 2018), the number of florets per head and the number of plants per ha.

\section{Conclusions}

Our study showed that abiotic environmental conditions, such as air temperature, impacted the secreted sugar mass per sunflower floret, with minimum, optimum and maximum temperatures that remain to be accurately assessed. The air humidity impacted sugar concentration, highlighting the need to analyse nectar secretion based upon sugar mass rather than nectar volume. However, we could not observe a soil water tension effect, probably due to a limited range of variation encountered for this factor.

We also were able to highlight a variation range of more of $100 \%$ in sugar mass secreted per floret between different current sunflower hybrids, but with no evidence for reduced sugar yield between oleic and linoleic cultivars, between current cultivars compared to those grown in 1980-2000, or between very self-fertile and less self-fertile cultivars. Studies therefore remain to be carried out to assess and potentially explain the poor honey yields reportedly encountered at present by beekeepers placing their honey bees on sunflower crops. Other variables may need to be considered, such as the floret length, which could limit the access of bees to nectar when florets are too long (see Mallinger and Prasifka, 2017; Portlas et al., 2018), or the number of colonies per crop unit area, since the sunflower crop area in France was divided by almost two between the 1985-1995 and the 2000-2010 years (FAOSTAT, 2020; see Figure 1 in Chabert et al., 2019).

Finally, the advantages of using the method that measures the nectar gross secretion rate were discussed, as the assessment of a secretion rate in $\mu \mathrm{g}$ of sugar per hour.

\section{Funding sources}

This work was supported by Syngenta ${ }^{\circledR}$, Arterris Innovation and Agrosolutions. These sponsors contributed to the study design and to the data collection.

Acknowledgements. We thank Isabelle Besse and Angélique Nicoli for the administrative management of the sunflower test plots, Mathieu Mourereau for providing meteorological data, and Marc Amiot, Jean-Paul Andrieu, Gilles Gree, Attila Kovacs, Sylvain Lascabettes and Alexandr Tsybulskiy for providing the data on self-fertility rate of sunflower. We are also very grateful to Felicity Vear for critical reading of the manuscript. We thank one anonymous reviewer for her/his constructive comments that enabled us to improve the manuscript.

Conflicts of interest. The authors declare that they have no conflicts of interest in relation to this article. The cultivars that are subject of this study were coded for confidentiality reasons.

\section{Authors' contributions}

B.E.V., C.S., A.F., A.B., G.C., E.C., C.C. and A.T. conceived the study, J.P., F.R., E.N., O.G., V.G., S.L. and C.M. performed field work, S.D. sowed and monitored the sunflower test plots, S.C. analysed the data, S.C. and B.E.V. wrote the manuscript. All authors gave final approval for publication.

\section{References}

Allen RG, Pereira LS, Raes D, Smith M. 1998. Crop evapotranspiration. Guidelines for computing crop water requirements. FAO Irrigation and drainage paper 56. FAO 300(9): D05109.

Bates D, Maechler M, Bolker B, Walker S. 2015. Fitting linear mixedeffects models using lme4. J Stat Soft 67(1): 1-48.

Baty F, Ritz C, Charles S, Brutsche M, Flandrois JP, DelignetteMuller ML. 2015. A toolbox for nonlinear regression in R: the package nlstools. J Stat Soft 66: 1-21.

Benjamin DJ, Berger JO, Johannesson M, et al. 2018. Redefine statistical significance. Nat Hum Behav 2(1): 6-10.

Bertazzini M, Forlani G. 2016. Intraspecific variability of floral nectar volume and composition in rapeseed (Brassica napus L. var. oleifera). Front Plant Sci 7: 288.

Bolker BM. 2008. Ecological models and data in R. Princeton: Princeton University Press.

Boose DL. 1997. Sources of variation in floral nectar production rate in Epilobium canum (Onagraceae): implications for natural selection. Oecologia 110(4): 493-500.

Breeze TD, Boreux V, Cole L, et al. 2019. Linking farmer and beekeeper preferences with ecological knowledge to improve crop pollination. People Nat 1(4): 562-572.

Burnham KP, Anderson DR. 2002. Model selection and multimodel inference: a practical information-theoretic approach. Berlin (Germany): Springer.

Búrquez A, Corbet SA. 1991. Do flowers reabsorb nectar? Funct Ecol 5(3): 369-379.

Carroll AB, Pallardy SG, Galen C. 2001. Drought stress, plant water status, and floral trait expression in fireweed, Epilobium angustifolium (Onagraceae). Am J Bot 88(3): 438-446.

Carruthers JM, Cook SM, Wright GA, et al. 2017. Oilseed rape (Brassica napus) as a resource for farmland insect pollinators: quantifying floral traits in conventional varieties and breeding systems. GCB Bioener 9(8): 1370-1379.

Castellanos MC, Wilson P, Thomson JD. 2002. Dynamic nectar replenishment in flowers of Penstemon (Scrophulariaceae). Am J Bot 89(1): 111-118.

Cerrutti N, Pontet C. 2016. Differential attractiveness of sunflower cultivars to the honeybee Apis mellifera L. OCL 23(2): D204.

Chabert S, Lemoine T, Fronteau L, Vaissière BE. 2017. Mesurer la sécrétion nectarifère : exemple d'une lignée hybride F1 et de son parent mâle stérile chez le colza d'hiver (Brassica napus L.). OCL 24(6): D602.

Chabert S, Lemoine T, Cagnato MR, Morison N, Vaissière BE. 2018. Flower age expressed in thermal time: is nectar secretion synchronous with pistil receptivity in oilseed rape (Brassica napus L.)? Environ Exp Bot 155: 628-640.

Chabert S, Sénéchal C, Benoist A, et al. 2019. Tournesol : la pollinisation au service du rendement. Phytoma 729: 45-49. 
Corbet SA. 2003. Nectar sugar content: estimating standing crop and secretion rate in the field. Apidologie 34(1): 1-10.

Cruden RW, Hermann SM. Studying nectar? Some observations on the art. In: Bentley B, Elias T, eds. The biology of nectaries. New York (USA): Columbia University Press, 1983, pp. 223-241.

Cruden RW, Hermann SM, Peterson S. Patterns of nectar production and plant-pollinator coevolution. In: Bentley B, Elias T, eds. The biology of nectaries. New York (USA): Columbia University Press, 1983, pp. 80-125.

Dafni H, Lensky Y, Fahn A. 1988. Flower and nectar characteristics of nine species of Labiatae and their influence on honeybee visits. J Apic Res 27(2): 103-114.

Descamps C, Quinet M, Baijot A, Jacquemart AL. 2018. Temperature and water stress affect plant-pollinator interactions in Borago officinalis (Boraginaceae). Ecol Evol 8(6): 3443-3456.

Descamps C, Marée S, Hugon S, Quinet M, Jacquemart AL. 2020. Species-specific responses to combined water stress and increasing temperatures in two bee-pollinated congeners (Echium, Boraginaceae). Ecol Evol 10(13): 6549-6561.

FAOSTAT. 2020. Food and Agriculture Organization of the United Nations Statistics Division. Available from http://www.fao.org/ faostat/en/\#home.

Findlay N, Reed ML, Mercer FV. 1971. Nectar production in Abutilon III. Sugar secretion. Aust J Biol Sci 24(3): 665-675.

Galetto L, Bernardello G. 2004. Floral nectaries, nectar production dynamics and chemical composition in six Ipomoea species (Convolvulaceae) in relation to pollinators. Ann Bot 94(2): 269-280.

Gallagher MK, Campbell DR. 2017. Shifts in water availability mediate plant-pollinator interactions. New Phytol 215(2): 792802.

Gillespie S, Long R, Williams N. 2015. Indirect effects of field management on pollination service and seed set in hybrid onion seed production. J Econ Entomol 108(6): 2511-2517.

Grossiord C, Buckley TN, Cernusak LA, et al. (2020). Plant responses to rising vapor pressure deficit. New Phytol 226(6): 1550-1566.

Hadisoesilo S, Furgala B. 1986. The effect of cultivar, floral stage and time of day on the quantity and quality of nectar extracted from oilseed sunflower (Helianthus annuus L.) in Minnesota. Am Bee J 126(9): 630-632.

Ion N, Stefan V, Ion V, Fota V, Coman R. 2007. Results concerning the melliferous characteristics of the sunflower hybrids cultivated in Romania. Sci Pap Anim Sci Biotech 40(2): 80-90.

Johnson VE. 2013. Revised standards for statistical evidence. Proc Natl Acad Sci 110(48): 19313-19317.

Kenoyer LA. 1917. Environmental influences on nectar secretion. Bot Gaz 63: 249-365.

Kuznetsova A, Brockhoff PB, Christensen RHB. 2017. 1merTest package: tests in linear mixed effects models. J Stat Soft 82(13): $1-26$.

Leiss KA, Klinkhamer PGL. 2005. Genotype by environment interactions in the nectar production of Echium vulgare. Funct Ecol 19(3): 454-459.

Lindström SAM, Klatt BK, Smith HG, Bommarco R. 2018. Crop management affects pollinator attractiveness and visitation in oilseed rape. Basic Appl Ecol 26: 82-88.

Luo EY, Ogilvie JE, Thomson JD. 2014. Stimulation of flower nectar replenishment by removal: a survey of eleven animal-pollinated plant species. J Pollinat Ecol 12(7): 52-62.

Mallinger RE, Prasifka JR. 2017. Bee visitation rates to cultivated sunflowers increase with the amount and accessibility of nectar sugars. J Appl Entomol 141(7): 561-573.

Masalia RR, Temme AA, de leon Torralba N, Burke JM. 2018. Multiple genomic regions influence root morphology and seedling growth in cultivated sunflower (Helianthus annuus L.) under well-watered and water-limited conditions. PLoS One 13 (9): e0204279.

Mesquida J, Marilleau R, Minh-Hà PD, Renard M. 1988. A study of rapeseed (Brassica napus L. var. oleifera Metzger) flower nectar secretions. Apidologie 19(3): 307-318.

Mione T, Diaz, IA. 2020. Dracula's mistress: removal of blood-red floral nectar results in secretion of more nectar. Plant Ecol Evol 153(1): 59-66.

Mueller AL, Berger CA, Schittenhelm S, Stever-Schoo B, Dauber J. 2020. Water availability affects nectar sugar production and insect visitation of the cup plant Silphium perfoliatum L. (Asteraceae). $J$ Agron Crop Sci, in press.

Nepi M, Stpiczyńska M. 2008. The complexity of nectar: secretion and resorption dynamically regulate nectar features. Naturwissenschaften 95(3): 177-184.

Nakagawa S, Schielzeth H. 2013. A general and simple method for obtaining $R^{2}$ from generalized linear mixed-effects models. Methods Ecol Evol 4: 133-142.

Nicolson SW. 1993. Low nectar concentrations in a dry atmosphere: a study of Grevillea robusta (Proteaceae) and Callistemon viminalis (Myrtaceae). S Afr J Sci 89(10): 473-477.

Nicolson SW. 1995. Direct demonstration of nectar reabsorption in the flowers of Grevillea robusta (Proteaceae). Funct Ecol 9(4): 584-588.

Ouvrard P, Quinet M, Jacquemart AL. 2017. Breeding system and pollination biology of Belgian oilseed rape cultivars (Brassica napus). Crop Sci 57(3): 1455-1463.

Pacini E, Nepi M. Nectar production and presentation. In Nicolson SW, Nepi M, Pacini E, eds. Nectaries and nectar. Dordrecht (The Netherlands): Springer, 2007, pp. 167-214.

Pacini E, Nepi M, Vesprini JL. 2003. Nectar biodiversity: a short review. Plant Syst Evol 238(1-4): 7-21.

Petanidou T, Goethals V, Smets E. 2000. Nectary structure of Labiatae in relation to their nectar secretion and characteristics in a Mediterranean shrub community-Does flowering time matter? Plant Syst Evol 225(1-4): 103-118.

Petanidou T, Smets E. 1996. Does temperature stress induce nectar secretion in Mediterranean plants? New Phytol 133(3): 513-518.

Phillips BB, Shaw RF, Holland MJ, et al. 2018. Drought reduces floral resources for pollinators. Glob Change Biol 24(7): 32263235 .

Pierre J, Emeillat R. 2009. Les variétés de colza actuelles sont-elles peu nectarifères pour les abeilles ? Bull Tech Apic 36(1): 17-24.

Pierre J, Mesquida J, Marilleau R, Pham-Delègue MH, Renard M. 1999. Nectar secretion in winter oilseed rape, Brassica napusquantitative and qualitative variability among 71 genotypes. Plant Breed 118(6): 471-476.

Portlas ZM, Tetlie JR, Prischmann-Voldseth D, Hulke BS, Prasifka JR. 2018. Variation in floret size explains differences in wild bee visitation to cultivated sunflowers. Plant Genet Res 16(6): 498-503.

Prasifka JR, Mallinger RE, Portlas ZM, et al. 2018. Using nectarrelated traits to enhance crop-pollinator interactions. Front Plant Sci 9: 812 .

Pyke GH. 1991. What does it cost a plant to produce floral nectar? Nature 350(6313): 58-59.

Raw GR. 1953. The effect on nectar secretion of removing nectar from flowers. Bee World 34(2): 23-25.

R Core Team. 2015. R: a language and environment for statistical computing. Vienna, Austria: R Foundation for Statistical Computing. Available from http://www.R-project.org/.

Sammataro D, Erickson EH, Garment MB. 1985. Ultrastructure of the sunflower nectary. J Apic Res 24(3): 150-160. 
Southwick EE. 1984. Photosynthate allocation to floral nectar: a neglected energy investment. Ecology 65(6): 1775-1779.

Suni SS, Ainsworth B, Hopkins R. 2020. Local adaptation mediates floral responses to water limitation in an annual wildflower. $\mathrm{Am} \mathrm{J}$ Bot 107(2): 209-218.

Szabo TI. 1982. Nectar secretion by 28 varieties and breeder's lines of two species of rapeseed (Brassica napus and Brassica campestris). Am Bee J 122(9): 645-647.

Takkis K, Tscheulin T, Petanidou T. 2018. Differential effects of climate warming on the nectar secretion of early-and lateflowering Mediterranean plants. Front Plant Sci 9: 874.

Takkis K, Tscheulin T, Tsalkatis P, Petanidou T. 2015. Climate change reduces nectar secretion in two common Mediterranean plants. AoB PLANTS 7: plv111.

Tepedino VJ, Parker FD. 1982. Interspecific differences in the relative importance of pollen and nectar to bee species foraging on sunflowers. Environ Entomol 11(1): 246-250.

Tonin P. 2018. Les productions françaises d'oléagineux de spécialité: des démarches en filière pour créer de la valeur dans nos territoires. OCL 25(2): D203.

Vear F, Pham-Delegue M, Tourvieille de Labrouhe DT, et al. 1990. Genetical studies of nectar and pollen production in sunflower. Agronomie 10: 219-231.
Villarreal AG, Freeman CE. 1990. Effects of temperature and water stress on some floral nectar characteristics in Ipomopsis longiflora (Polemoniaceae) under controlled conditions. Bot Gaz 151(1): 5-9.

Waser NM, Price MV. 2016. Drought, pollen and nectar availability, and pollination success. Ecology 97(6): 1400-1409.

Wist TJ, Davis AR. 2006. Floral nectar production and nectary anatomy and ultrastructure of Echinacea purpurea (Asteraceae). Ann Bot 97(2): 177-193.

Wist TJ, Davis AR. 2008. Floral structure and dynamics of nectar production in Echinacea pallida var. angustifolia (Asteraceae). Int J Plant Sci 169(6): 708-722.

Wyatt R, Broyles SB, Derda GS. 1992. Environmental influences on nectar production in milkweeds (Asclepias syriaca and $A$. exaltata). Am J Bot 79(6): 636-642.

Yan W, Hunt LA. 1999. An equation for modelling the temperature response of plants using only the cardinal temperatures. Ann Bot 84(5): 607-614.

Yin X, Kropff MJ, McLaren G, Visperas RM. 1995. A nonlinear model for crop development as a function of temperature. Agric Forest Meteorol 77: 1-16.

Zajácz E, Zaják Á, Szalai EM, Szalai T. 2006. Nectar production of some sunflower hybrids. J Apic Sci 50(2): 109-113.

Cite this article as: Chabert $\mathrm{S}$, Sénéchal $\mathrm{C}$, Fougeroux A, Pousse J, Richard F, Nozières E, Geist O, Guillemard V, Leylavergne S, Malard C, Benoist A, Carré G, Caumes É, Cenier C, Treil A, Danflous S, Vaissière BE. 2020. Effect of environmental conditions and genotype on nectar secretion in sunflower (Helianthus annuus L.). OCL 27: 51. 